\title{
The Virtual World of Pynchon's Fabulation: Against the Day Lit World
}

\author{
Razieh Rahmani \\ University of Tehran, Iran; \\ The State University of New York at Binghamton, USA
}

\begin{abstract}
Adapting Deleuze's conceptualization of the virtual, this study shows that Against the Day intends to undermine our narrow conception of reality by surpassing the actualities of the known world. In the darkness of the novel, "the virtual" lurks; the novel is a travel against the day, against the actual world to an actualvirtual world, toward "the nights" which "will be dark enough for whatever visions must transpire across them, no longer to be broken into by light" (Pynchon, 2006, 1083). ${ }^{1}$ Indeed, the presence of mysterious, paranormal, and magical events (such as the uncanny tales of ghosts, séances, visions, hallucinations, and other-dimensional interventions) along with actual events functions as a defiant modus operandi against the actual-oriented, secular Western Philosophy. That is, through virtual occurrences, lines of flight are created (from the real/actual) offering alternative systems of looking at the world.
\end{abstract}

Index Terms - the virtual, fabulation, Against the Day, Pynchon, Deleuze

"Let us create extraordinary words, on condition that they be put to the most ordinary use and that the entity they designate be made to exist in the same way as the most common object."

$$
\text { — Gilles Deleuze, Dialogues }
$$

Deleuze's reference to Marcel Proust's statement, "Real without being actual, ideal without being abstract" (Deleuze, 1994, p. 208), can best describe the concept of the virtual. To Deleuze, experience is a not confined perception, and there is always something beyond what we perceive actually, something virtual which is directly related to the actual experience yet is incorporeal, some line of flight from the actuality which is real although "we don't see it, because it's the least perceptible of things" (Deleuze, 1995, p. 45). The virtual is part of reality, and these incorporeal territories are virtually real though they might not be actualized in the visible world of everyday existence. In Against the Day, Pynchon tends to transcend the world we are experiencing through our five senses by engaging in the virtual, the unknowable, and the invisible. Indeed, the reader's relationship to the reality is destabilized as soon as the narrator enters the realm of virtual straying away from the pedestrian realm of the actual, representation, and sensible signification. In Dialogues, Deleuze contrasts French literature with minor literature in which there is no longer the infinite account of interpretations which are always slightly disgusting, but finite processes of experimentation, protocols of experience. Kleist and Kafka spent their time making programmes for life. Programmes are not manifestos - still less are they phantasms, but means of providing reference points for an experiment which exceeds our capacities to foresee. (Deleuze and Parnet, 1987, p.48)

In the same vein, Against the Day, though fictional and fantastical, is arguably a set of programs for real life, programs which are "means of providing reference points for an experiment which exceeds our capacities to foresee" (Against, p. 48). In the synopsis of the book, Pynchon describes the novel as the world as such or the world "with minor adjustment or two", and "[a]ccording to some, this is one of the main purposes of fiction." Pynchon is after presenting the reality of the world, a "hysterical" reality (in Wood's terms) which might differ from the reality offered by the actual-oriented realist writers, yet it might be truer to the reality of the world. ${ }^{2}$ In the synopsis, Pynchon states that he is not to merely depict the actual present time of the novel in a so-called realistic fashion, rather he wants a deeper reality which is gained by manipulating the actual history and incorporating the virtual into the actual and present society. Interestingly, Buchanan (2000) posits a similar argument about Deleuze's own writings; he says, "the most deeply utopian texts are not those that propose or depict a better society, but those that carry out the most thoroughgoing destruction to the present society" (p.94).

Deleuze and Guattari (1994) in What is Philosophy propose that art incorporates or embodies the virtual, leaving space for "life higher than the "lived" (p.177) that is higher than the actual. Generally, fiction contributes to the revelation of the virtual realms of life in that by reading it, the reader dissociate himself from the actual world surrounding him and creates a more virtual-oriented outlook. John Hughes (1997) also argues that an artwork is itself a virtual event:

\footnotetext{
${ }^{1}$ Hereafter, Pynchon's Against the Day (2006) is referenced to as Against.

${ }^{2}$ As Fowler (1980) argues in A Reader's Guide to Gravity's Rainbow, Pynchon "does not enter into any covenant with the reader as to what is 'real' and what is 'fantastic.' His fiction is fantastic in its essence, not incidentally or symbolically;" that is, Pynchon "does not hold up a mirror to nature, but steps through the looking glass into a realm governed by magical forces rather than logical ones" (p. 55).
} 
So, the artwork takes on the status of an event of the virtual expressed through its matter as a reiterable potential of relations exceeding any states of affairs that is depicted. The affect becomes sensible in the matter of expression [...]. As an event, the artwork reiterates the potentialities which insist within its sensible material. (p. 70)

Likewise, Pynchon dexterously interweaves what is happening in our everyday routine with what "exceed[s]any states of affairs"; he creates odd events and ideas which make even more sense than the actual ones, granting us a holistic and deep reality hence "the actualizations expressive of the virtual affect incorporated in the material of art" (Hughes, 1997, p. 71). Pynchon's characters are living within an actual-virtual reality that can be traced in the actual and virtual events coexisting naturally side by side. As Kathryn Hume (2011) points out, "characters in Against the Day long to go beyond the material world to something higher and finer, and they sense that higher reality through mathematics, light, vision, peyote, a geographical sacred place, or floating in an airship" (p. 177). Indeed, Pynchon's artistic and literary experimentations necessitate thinking events at the level of the virtual.

\section{THE CONCEPT OF VIRTUAL}

Deleuze insists that his philosophy is "transcendental empiricism"; thus, he tends to surpass the actual world we sense through our five senses. Deleuze's virtual, which is pivotal in the Deleuzian philosophy, is comparable to Kant's concept of noumenon in going beyond the phenomenal (what is apprehended by the five senses). Deleuze (1994) states, "The virtual must be defined as strictly part of the real object -- as though the object had one part of itself in the virtual into which it plunged though into an objective dimension" (p. 209). The ramifications of the virtual concept are multiple since it is interrelated to many other concepts like multiplicity, difference, and becoming given that difference and becoming are nothing else than the creative process of unfolding the virtual, i.e., the actualization of the virtual in multiple actualized beings. Deleuze (1988) argues, "the virtual differenciates itself; without this the virtual could not be actualised because there would be no lines of differenciation that could enable actualisation to happen" (p. 97). Indeed, Deleuze has characterized the virtual as the élan vital which is the internal spontaneous force in the morphogenesis of things. He claims that the "virtual difference" has the potentiality "to become in unforeseen ways," ways which are "always more that this actual world, and not limited by its already present forms" (Colebrook, 2002, p. 96).

The world consists of actualities and virtualities, that is, the actual state of affairs and the multitude virtualities potential in life. ${ }^{1}$ The virtual force is difference-in-itself and the virtual power of life is its potential to differ. Then, life is a virtual power of singular variation, and through this standpoint, we can grasp the world's virtual power, a world of multiplicity, immanence, and becoming which yields infinite difference.

A LIFE and nothing else [...] A life is the immanence of immanence, absolute immanence: it is complete power, complete bliss [...]A life is everywhere, in all the moments that a given living subject goes through and that are measured by given lived objects: an immanent life carrying with it the events or singularities that are merely actualized in subjects and objects ... A life contains only virtuals. It is made up of virtualities, events, singularities. (Deleuze, 2001, p.29)

Deleuze's emphasis on the virtual is in line with the prominence he gives to difference as both concepts criticize western philosophy which is rather based on the actual and identity. Thus, unlike what the traditional philosophy holds, Deleuze claims that the real world is not merely composed of the actual but also the unactualized virtual; he argues, "Every actual surrounds itself with a cloud of virtual images. This cloud is composed of a series of more or less extensive coexisting circuits, along which the virtual images are distributed, and around which they run" (Deleuze, 1977, p.148).

\section{FABULATION}

Gregory Flaxman (2012) states, "the most elusive aspect of minor literature" is "the power of fabulation" or "the power of the false" (p. 234). He argues that Deleuze is a philosopher of the false and fabulation who privileges simulacrum (or the "falsehood" of a simulacrum) over Platonic truth. Flaxman holds that Deleuze himself "turns to the work of art because, especially in its literary formation, it musters the powers of the false to create the "impossible"" (Flaxman, p.183). Also, Fairclough, conceding to the performative nature of discourse and fiction, states, "Discourses not only represent the world as it is (or rather is seen to be), they are also projective, imaginaries, representing possible worlds which are different from the actual world, and tied in to projects to change the world in particular directions" (Fairclough, 2003, p.11). Indeed, the powers of the false are to create the "impossible" and go beyond representing the possible worlds. Fabulation is to activate the "powers of the false", "to falsify orthodox truths in the process of generating emergent truths" (Bogue, 2011, p. 81). Fabulation comprises resistance given that "to create is to resist" (Deleuze and Guattari, 1994, p. 110); hence, fabulation is political. Fabulation is the process of creating "the new, remarkable, and interesting" (p. 111), and fiction via its discourse has the power to (re)constitute the world. What fiction does is similar to Heidegger's projection introduced in Being and Time which is "a throwing of existence ahead of itself' (Roe, 2003, p. 3).

\footnotetext{
${ }^{1}$ The "virtual and the actual are two mutually exclusive, yet jointly sufficient, characterizations of the real" (Boundas 2014, p. 490).
} 
Similarly, the events of Pynchon's text, getting loose from the actual world, tend not to be restricted to the possibilities, and extend themselves into the virtual realm; thus, we are faced with narrative-virtual or virtual-oriented fabulation. Flaxman argues that Kafka considers "the strange task of writing" "a kind of creationism" that connotes "the possibility of an event, which [...]set[s] the 'real world' ablaze, burning it to the ground [...] and then creating an entirely new one in its place" (Flaxman, 2012, p. 235). Indeed, Kafka intends to say how "the strangest fancies" unleash "lines of flight that leave the world behind" (p. 235). Similarly, going beyond traditional historicizing which is based on actual encounters, Pynchon's fabulation tends to resist the tyrannical reduction of the reality to the actual. Against the Day hinges on the spectacle of "the strangest fancies", the unexplained, and the unexplainable; that is, in the novel we encounter fantastic violations of the laws of actual realm, the laws of space, time, thermodynamics, and even mortality. Deleuze believes, "to write is to become" (Deleuze and Parnet, 1987, p.32), and the idea that literature is far from reality because of engaging in the imaginary and fictitious is debunked by him. ${ }^{1}$ There are many mundane actual events in Against the Day, but the narrator always leaves some space for the defiant powers of the spiritual and the supernatural possibilities. Yashmeen Halfcourt, a major protagonist, explains about going beyond the "galley-slave repetition of days" and being able to go deeper, that is, the capability of stepping "outside of Time as it commonly passes here" (Against, p.610). Indeed, the title of the novel, Against the Day, which has been a riddle perplexing many, could be a cue for the whole mammoth work. According to the narrator of the novel, there are ways which "God chose to hide within the light of day" (Against, p.853), and beyond this light of actual world, there is "God's unseen world" which has been avoided by the actual-oriented realist writers with a myopic, actual-oriented outlook, while Pynchon has tried to incorporate it in his fantastic work.

\section{The VirTual in A Gainst the DAY}

In the delightful labyrinthine narrative of Against the Day, anything is entirely possible. Recounting the historical period from 1893 until the time following World War I in around 1100 pages, the book does not merely focus on actualities or even possibilities, but also virtualities are immensely and inseparably intertwined. Indeed, the narrative of Against the Day grows out of the actual historical state of affairs without any boundaries on where and when the actual events veer into virtual ones. This is compatible with the Deleuzian view in which the reality is consisted of the actual and the virtual inseparably joined. For instance, the actual historical events are juxtaposed with the Chums of Chance's wandering around the world in their out-of-this-world zeppelin in search of other-dimensional entities and events that go beyond the actualities' boundaries like Æther, Iceland spar, time machines, wanderers from the future (Trespassers), and the mysterious Tunguska Event. This is because "the unnaturally shaky quality of present-day "reality" (Against, p.518), as Pynchon puts it, cannot be conveyed via the traditional, actual-oriented outlook on the world. The idea behind Against the Day's transgression of actualities and all those fantastical possibilities commingled with historical actualities is to show the virtual possibilities, or better, potentialities inherent in the world.

Pynchon's novel is replete with whimsies, shenanigans, and intriguing events. Pynchon teases the reader out of his premises that the reality equals the actual entities and things surrounding him and piques his insight into reality by exposing him to a world beyond his ordinary grasp. Pynchon fashions alternative worlds, and these fantastic inventions have a wonderful force of the inventiveness and virtuality. His indulgence in the fantastical events which are "from somewhere else not quite "in' the world" is to render the virtual/real of the world; that is, the events seem to be nonexistent and non-actual, yet they are real in a Deleuzian sense. At a point in Against the Day, for instance, Yashmeen Halfcourt experiences a mystifying twilight with a curious pallor in Vienna that lasts for a month; it is "cringed beneath the sky" and carries "the sense of overture and possibility", a possibility beyond what we actually encounter in the everyday world.

As nights went on and nothing happened and the phenomenon slowly faded to the accustomed deeper violets again, most had difficulty remembering the earlier rise of heart, the sense of overture and possibility and went back once again to seeking only orgasm, hallucination, stupor, sleep to fetch them through the night and prepare them against the day. (Against, p.805)

This is the realms of "possibility" beyond the logic of everyday empiricism, a virtual being actualized in the realm of the novel and changed to a routine affair for the characters of the novel, although remaining virtual to the readers; as Deleuze and Guattari (1994) argue, the work of art essentially "does not actualize the virtual event but incorporates or embodies it" (p. 178). No wonder Deleuze and Guattari (1987) have dubbed the writer a "sorcerer" (p.240), a sorcerer who has access to the virtual and incorporates it in his writing. Ironically, Pynchon makes one of his characters talk about this going beyond the so-called "real"; as Kit Traverse escaping from a mysterious death intrigue by a flow of mayonnaise, exclaims, "Nothing's been rigorously what you'd call 'real' lately". That is to say, Pynchon is after depicting "life higher than the "lived"" in Deleuzian words (Deleuze and Guattari, 1994, p.178), or beyond what "you'd call 'real'," in Pynchon's words. The novel confronts its readers with an undercutting force of the beyond pushing them to have their own reality construction; when the imagination has gone wild, it is revealed that bigger picture to the reader is forming a new reality, a political one in Deleuzian sense, no longer confined by the controlling, stifling frames

\footnotetext{
${ }^{1}$ Koerner (2002) says, "Literature does not represent an imaginary world, nor can it be reduced to the nature of previously exi sting symbolic structures; instead, literature produces the real" (p. 13).
} 
of the actualities. Indeed, the novel is an altar for the marriage of the metaphysical and the socio-political spheres and amalgamation of epistemological and ontological issues which "literally transcend the old political space, the mapspace of two dimensions, by climbing into the third" (Against, p.1083). Inger H. Dalsgaard states in his essay on this novel, "When reading fictions," "we may be in a better position to maintain a conscious awareness of alternative narrative realities coexisting with equal validity than we are in our everyday experience" since in our actual-oriented everyday experience "we usually privilege one reality and read others as 'ghosts,' dreams, or fantasies" (Against, p. 122). In the fictious world of Against the Day, there are all these elements of ghosts, dreams, or fantasies related to "alternative narrative realities" (or the virtual realm) which coexist with the everyday experience (or the actual realm).

Pynchon in his article "Is it OK to be a Luddite?" states that the mysterious archetypes such as "the Badass -- the djinn, the golem, the hulk, the superhero" undercut the traditional frames of "the real or secular." Likewise, his novel's postsecular uncanny critters are to bash the same "real or secular" frames. He creates animals that do not comply with the actual animals around us. A telling example is the spine-chilling, gigantic worm called Tatzelwurm. Tatzelwurm (i.e., pawed worm) is a mysterious, subterranean creature that can stand for "some primordial plasm of hate and punishment" (Against, p.655) in the bowels of the Earth. ${ }^{1}$ Indeed, Pynchon uses an eco-critical discourse at this point. Giving virtual quality to the phantasmagoric creature, he makes them embody the dormant, virtual force of the nature, a nature which has hitherto remained reticent in response to the violations of technology, but suddenly, it cannot not take it anymore unleashing its virtual anger via its soldier-worms. In the realm of the underground, this burrowing creature is a malignant/benign force with a virtual potentiality to take on various good or evil-primordial forms which "can be projected to the surface" either as a gruesome retaliating creature of the rage of the nature or as a benign masculine force to protect the feminine Earth from evil men-- evil men who exploit and corrupt the Mother Nature by their intrusion into it, drilling into it, by raping her (i.e., creating the tunnels under the Alps) for the sake of advancing technology. Indeed, Tatzelwurm has an indefinite incorporeal potential that is actualized in diverse corporeal manifestation. Moreover, this unpredictably volatile creature resists the actual features of vision; that is, Pynchon has created it as a virtual image which is capable of shifting. In other words, the monstrous creature is a virtual image which does not have an exact fixed representation in the actual world. The Tatzelwurm, as a virtual image, is capable of irrupting in the nightmares of the owners, i.e., Pynchon's movement from actual manifestation of the force to its virtual image. These delirious projections function as a "flight"; as Deleuze explains to Parnet:

A flight is a sort of delirium. To be delirious is exactly to go off the rails (as in deconner - to say absurd things, etc.). There is something demoniacal or demonic in a line of flight. Demons are different from gods, because gods have fixed attributes, properties and functions, territories and codes: they have to do with rails, boundaries and surveys. What demons do is jump across intervals, and from one interval to another. (Deleuze and Parnet, 1987, p.40)

Philippe who has "gained an early appreciation of institutional spaces" compares the underground world of Tatzelwurms with a cathedral, and the Tatzelwurms with priests "of their own dark religion" (Against, p.658) signifying the mystery and obscurity of an irate Nature's virtual force, nature's dark side.

Yet, another phantasmagoric creature which is the embodiment of the nature's anger is the monster which is dig from North pole's ground and transported to the city and wreaks destruction on the city. This dreadful object could be the representation of the "invisible ruler" which is "in general not friendly" and "an enforcer of ancient, indeed prehuman, laws" which are now violated by humans (Against, p.150-51). The "serpent like" creature (Against, p.141) instills "contempt" in the greedy humans and dominates human with its vengeful gaze. The unearthed monster seems to be a mystifying entity which is unnamed and unidentified and undescribed with "little agreement" "as to its 'facial' features" (p.141). Indeed, the critter has a dynamic nature, and this potentiality of being dynamic and unpredictable is what makes it more "virtual" in the Deleuzian sense. When Chums place it in the ship they realize that the dimensions and shape of the entity is dynamic: "Trying to get it to fit inside the ship, we measured, and re-measured, and each time the dimensions kept coming out different—not just slightly so but drastically. There seemed no way to get the object through any of the ship's hatches" (Against, p.144). The scientists fail to "determine the distribution of its weight in ordinary space", that is actual space, with their actual-oriented science and measuring tools because this creature is pregnant with some virtual forces that enables it to be different any minute. Indeed, Pynchon incorporates this virtual, hazardous, volatile, once-buried giant of him into the actual-oriented, technological, capitalistic metropolis to imbue the world of his novel with the virtual energies. ${ }^{2}$

Besides, there are purposeful narrative ellipses which contribute to the virtuality of the monster and the mystery of the crazed narrative. Pynchon's horror scene, the nameless creature's rampage, and most importantly the exact nature of the creature are shrouded in mystery. The aftermath is depictured briefly wherein "Fire and blood were about to roll like fate upon the complacent multitudes" (Against, p.152). Though there are minute nuances regarding the victims and the

\footnotetext{
${ }^{1}$ Christopher Coffman (2011) also considers the earth as a conscious being counteracting against the advancements of human beings in a defensive fashion.

${ }^{2}$ Also there are Tommyknockers, mischievous spirits whose existence is denied by the capitalists with their actual-oriented, "every day explanations" (Against, p.308). Also, there are giant beetles (Against, p.991) that are the souls of people, and local people use their virtual quality of connectivity beyond space-time dimension to help further their mundane and actual affairs; that is because within the virtual realm of souls "Special Relativity" is not applicable (Against, p.992).
} 
wreck caused by the creature, the creature himself is cloaked in a mist of the traumatic scene of destruction rendering the city's inhabitants "amnesiac" and bemused (Against, p.153). This obscurity reinforces the sense that the creature has virtual potentialities; as if the monster is an invisible, ineffable, virtual force rather than an actual presence. Besides, the exact place and time remains undecided; therefore, the disaster has the potentiality to be the embodiment of many historical or human-made catastrophic events such as 9/11 terrorist attack, world wars, Hiroshima's nuclear bombardment, Holocaust, and even probable catastrophic events "yet to come" in possible future such as nuclear wars; thus, this event is a virtual "Event" having multiple temporal layers. Deleuze (1994) proposes the concept of "to come" which is a future in present that we don't know, and we cannot pin down, a future "at the frontiers of our knowledge" where we can start writing (p.xxi). A writer who can depict the "to come" can see beyond the actual time and get access into the alternative virtual time. Interestingly, the heroine of the novel seems to have access to these realms. Yashmeen, has the virtual potentialities "to travel in the fourth dimension" (Against, p.602); the fourth dimension supposedly refers to time since she talks of the ability to step "outside of Time as it commonly passes here, above this galley-slave repetition of days, and have had a glimpse of future, past, and present" (Against, p.610).

In this novel, natural entities seem to possess a virtual quality which could be actualized under certain circumstances and by certain people. For instance, there are virtual roses which have the ability to not only understand human language but also communicate with them using human language (Against, p.956). Also, Dr. Mikimoto produces cultured pearls which "When illuminated in a certain way" could "be made to yield a message" (Against, p.114). Indeed, in the process of light refraction, part of the cultured pearls' virtual force is actualized so the message on the pearls, which is already there but invisible and incorporeal, becomes visible to the corporeal eye.

There are also fabricated objects with virtual qualities. Some hours after Kit has come back from the "invisible" hospital, in the darkness of the dormitory, Kit sees an indistinct mass which smells of freshly-baked pastry. The oversize pastry starts to talk with Kit requesting him not to react because it fears if others know about its being there, they might eat it. The strange mass says his situation is similar to that of "invisibility" since most of the people cannot admit that they have seen it. It talks about the issue of cannibalism in a humorous syllogism:

"...And then the cannibalism issue of course."

"The ... I don't exactly ..."

"Well. Puts them in a bind, doesn't it. I mean, if I'm human, and they're considering me for breakfast, that makes them cannibals - but if I really am a jelly doughnut, then, being cannibals, they all have to be jelly doughnuts as well, don't you see?" He began to laugh merrily. (Against, p.627)

The concept of being beyond visibility, transgressing "the edges of the visible" (Against, p.297), and the "invisible forces" (p.362) which are "less nameable" (p.542) are reiterated all over the novel. Indeed, what Pynchon says about his character is applicable to Pynchon's own preferences: Lew Basnight has "a keen sympathy for the invisible" and this is indeed "what distinguish[es] him" (Against,p.43). As Deleuze argues, "Beneath the actual qualities and extensities, species and parts, there are spatio-temporal dynamisms [...] They must be surveyed in very domain, even though they are ordinarily hidden by the constituted qualities and extensities" (1994, p.214). Invisibility has to do with virtuality, given that the virtual is something which exists yet is not actual or visible. From Deleuzian perspective, for instance, the human eyes actualize light as color; however, there are other living things that actualize it in other ways. Therefore, "there is always more than the actual world; there are also all the potential worlds that we might see" (Colebrook, 2002, p.126). Indeed, "our perceived present has this virtual halo of what is not present but is no less real" (Colebrook , 2002, p.127); thus, real but invisible or "imperceptible". Human beings, especially artists can "expand and maximise difference: anticipating a future, recalling a past, and allowing the actual perception to be opened to the virtual" (Colebrook, 2002, p. 127). Pynchon's novel emphasizes the "invisible" al through the novel to the extent that it becomes one of the key words to the understanding of the novel. He tries not to reduce the chaos of perceptions to the visible, the actual, by going beyond the visible territory of humans. For instance, the Chums of Chance, who to the people "from the ground" are "more conjectural than literal" (Colebrook, 2002, p.255), grow more and more invisible as the novel proceeds. From some point in the novel onward, the earthly residents do not seem to be able to see Chums and their vessel anymore; as Randolph sadly complains, "they would have all been stopped in their tracks, rubbernecking up at us in wonder. Nowadays we just grow more and more invisible" (Against, p.549). Chums become invisible from "the known Creation" escaping into a space which is "beyond the space we know" (Against, p.602), or in Miles' terms "they actually become invisible. Almost as if there were some [...] additional level of encryption" (p.437). Moreover, Kit with a group of his classmates takes the overdosed Humfried to a hospital that is constructed "on the principles of Invisibilism." Indeed the structure of the hospital is "minimally attached to the physical world"; that is, the real/actual world (p.625). The wired girlfriend of Kit, Pleiade, also seems to have this asset of "deliverance into the Invisible" (Against, p.625) at her will. Pleiade wants to make Kit busy so that Piet can spy on Kit's room. "[A]gainst his better judgment", Kit accompanies Pleiade to her suite and there "with no sensible passage of time" (p.542), the rooms becomes "resonant with absence", and Pleiade vanishes mysteriously from the room out of blue, leaving her "all-but insubstantial chiffon" standing erect "against gravity" (p.543). The pale negligee is rippling now and then "from otherwise un-sensed passages of air, as if someone were inside of it, perhaps stirred by invisible forces less nameable" (p.542). Also, Pynchon aptly calls the mysterious city of Shambhala the "invisible sphere of force" (p.447). The sacred 
city, for centuries, "had lain invisible, cloaked in every day light" of actualities, until the Tunguska Event in which "those precise light frequencies which would allow human eyes to see the City" were finally released (p.793). ${ }^{1}$

Moreover, there is a "notional railway" (p.842) in Mitrovitsa that Cyprian and Danilo were following, which was "not yet built" standing "invisible across the snow and passes and valleys, an element of diplomacy waiting to enter material existence" (p.842). Indeed, Pynchon is deeply engaged with the virtual, and he is after presenting the "something else" which is "beyond the world" (Against, p.75) and beyond the visible in his novel; a good analogy could be drawn between these virtual, invisible entities and what a character describes as the waves which lay beyond the visible light, "wireless waves, [...] Seems every day somebody's discovering another new piece of the spectrum, out there beyond visible light" (p.670). Likewise, the Deleuzian virtual plane of existence is similar to the "other plane of existence, close but just invisible" (p.610) which Pynchon engages in so often. That is, Pynchon's "the invisible, the 'imaginary,' the unimaginable" (p.1082) is at times quite similar to Deleuzian virtual, the hidden. Virtual dimension of reality is a dimension which exists beyond the visible three, just like the Chums of Chance's motto "There, but Invisible," a virtual force that like "death" is "invisible and everywhere" or "like God" (p.835) as occurred to Danilo Ashkil.

Indeed, Pynchon presents a world of a dynamic reality rather than representing an actual world of immediate objects; he pushes the fiction into the realm of the virtual and lays bare the profound reality behind the actual one resulting in a creative reality whose audacious creativity does not make it any less real or genuine. One of the examples of the virtual possibilities Pynchon refers to is the possibility of "afterlife". Against the Day is replete with ghosts and communications with the dead via séances or prophetic dreams; by so doing, he creates lines of flight via the events which go stray from "insufferably smug guardians of the day lit world" (p.672). It is worth mentioning that the concept of death is virtual as such; Deleuze sees death, in its pre-individual or impersonal form, as an "eternal return" with a virtual force since it is the "ultimate manifestation of the active principle that drives all living matter" (Parr, p.152). This interconnection "with the "outside"" and being "on the frontiers of incorporeality" gives death a virtual nature. The employment of ghosts is both aesthetic and political in Deleuzian terms since the presence of ghosts in the novel functions as a resistance to the rationalistic tradition which is based on the observable, concrete presence, representation, and actual aspect of reality. Through dreams, visions, and séances, the characters have journeys to parallel worlds, meeting otherworldly beings such as ghosts and specters, visiting a world beyond the material, and gaining awareness they would never gain in actual world. Beside séance, the characters use another way to communicate with the dead, dream; indeed, the character's dreams and visions are so much recounted in the novel that they become a major motif in the novel with undeniably significant undertones. In Deleuze's view, dream has a virtual quality, and it is a line of flight or going off the rails of actualities; "[a] flight is a sort of delirium. To be delirious is exactly to go off the rails;"

"[t]here is something demonaical or demonic in a line of flight. Demons are different from gods, because gods have fixed attributes, properties and functions, territories and codes: they have to do with rails, boundaries and surveys. What demons do is jump across intervals, and from one interval to another" (Deleuze and Parnet, 1987, p. 40).

To Deleuze, dream is a transitional space that has the potentiality of deterritorialisation of the mundane actual world, reveals the imperceptible to us, and frees life from the actual-oriented and habitual modes of perception. Most importantly-- coming from the super-terrestrial sphere-- the "transcendent Webb['s]" ghost like the ghost of Hamlet's father frequently visits his sons in their dreams; every time Webb is going to communicate another message to his sons on order to spur them into taking revenge, finishing his unfinished business, or continuing his way. Soon after the séance summoning his father's spirit Kit dreams of his father. In that dream, Webb is playing poker solitaire, and Kit who is about six years old in the dream "notices at the time the cards are not only marked with numbers, they somehow are numbers, some real, some imaginary, some complex and even transcendent" (Against, p.673). The scrupulous Kit wakes up feeling guilty because he has betrayed his father's goals by accepting Foley's proposition of scholarship. Kit, "sick and hollow with shame", has no other way than to resort to "the stripped and dismal metonymies of the dead" in the virtual world of "séances and dreams" (p.674). Being a math scientist himself and believing in real numbers, Kit is faced with "some imaginary, some complex and even transcendent" ones and a virtual universe (of the dead) which exists in parallel, i.e., the "spirit realm[s]", the "coexisting world[s] of imaginaries" (p.675). Formerly, he was committed to Vectorism which had a glimpse of "transcendence", yet now he feels that Vectors never have been his "salvation" (p.675). Moreover, his father has been murdered by men whose allegiance "was to that real axis and nothing beyond it" (p.675); that is, they were utterly committed to the actual. Therefore, the inspiring dream causes Kit to set out for "someplace out ahead in the fog of futurity" (p.675) which -as it turns out - is Venice where Scarsdale Vibe will be, someone whose punishment Kit has avoided. Indeed, in this novel dreams can disclose invisible realms or parallel worlds and open the prospect of transition to a different mode of life since the reality, in Pynchon's viewpoint, does not merely lie in its actualities and visible entities but also in the sphere beyond the actual, a sphere which could be reflected in the dream world.

\section{People with Virtual Qualities}

${ }^{1}$ Interestingly, this is close to Deleuze's concept of "Event" which is closely related to the virtual force and a sort of the actualization of the virtual. 
The multiple layers of mysteries, magic, and super-terrestrial events and characters in Against the Day produce a virtual sphere which serves as a key to the Pynchonian style of writing. Hinging on the spectacle of the unexplained and the unexplainable, Pynchon creates characters with virtual qualities such as Merle, the alchemist; Yashmeen Halfcourt, the femme fatale; Lew Basnight, the mystifying detective; the Chums of Chance, the extra-terrestrial balloonists; and so forth. One of the major characters with virtual qualities is Yashmeen Halfcourt; at times, she is able to see beyond the actual world. In a letter to her father, Yashmeen describes some virtual visitors who are "lighted from within" by whose compassionate help she wishes "to transcend the World" (Against, p.749). However, Yashmeen is worried why the otherworldly visitors who used to visit her all the time, now do not come along and her only hope is to be "brought in among them someday." She starts doubting herself desperately wondering if she has lost her virtual privileges to see the "invisible" critters (p.750). She describes herself as a person with "strange doubleness"; one version of her is at Shambhala with her father and the other version of her who has "stayed behind" (p.750) is writing the letter. ${ }^{1}$ Moreover, Yashmeen has the qualities of a Shekhinah figure. Shekhinah is the actualization of the virtual powers of God; thus, without her, God will remain in the virtual realm, as Father Ponko puts it: "Without her to reflect, God is invisible" (Against, p.223).

Cyprian's "religious surrender of the self" (p.876) to Yashmeen as an image of the Shekhinah, is not merely a sexual subservience but a line of flight to the beyond; that is, this ascetic surrender of his body and his sexual desires, which seems masochistic, in a sense is a flight to a world beyond the actual, beyond the sadomasochistic sexual games into a transcendental, Gnosticist sphere. As Coffman (2011) argues, Cyprian achieves transcendence by means of “a declaration of allegiance to a female transcendent" (p.99). Indeed, Cyprian's self-willed abjection of self, subjectivity, and identity has to do with his subservience to spirituality as though he wants to go beyond the concept of subject and transgress the actual limits. The sexuality of Cyprian is virtual as such since it actualizes in polymorphous forms starting with being a male, to a transgender, and finally a female by crossing a mysterious stone gateway "Halkata Ring" that changes the sex of any bachelor who passes under it (Against, p.955).

Lew Basnight also reveals virtual qualities some of which come as a surprise to Lew himself as well as the reader since Lew who was once "the Upstate-Downstate Beast" (Against, p.37) seems to have drawn blank on his mysterious past. In fact, with his mystifying existence, Lew is stuck between a dreadful past (when he racks his mind to remember the past, "all he could produce was this peculiar haze" [Against, p.37]) he cannot retain and a complicated present he cannot figure out. This vagueness gives Lew's life a kind of virtual quality. He also experiences some surrealist visions, altered states of consciousness, strange mental states, and trances. He is able to witness the extraordinary realms from time to time.

Also, Lew has the capacity to see certain virtual images; once, he looks out of the window at the Wintery downtown Chicago, but when he looks closely the scene transforms into an eerie setting: "a mirage of downtown Chicago ascended to a kind of lurid acropolis" as though Chicago is devoured by the "lurid acropolis" as a "nightly immolation" (Against, p.41). Once, in a very usual an ordinary day, Lew undergoes a strange "transfigure[ation]" and finds himself "surrounded by a luminosity new to him, not even observed in dreams" (Against, p.42). At Another point, in a hotel, the wallpaper turns into "a very far away land perhaps not even on our planet" with "beings who resembled - though not compellingly-humans" and were busy with their lives "beneath the gigantic looming of a nocturnal city full of towers, domes, and spidery catwalks, themselves edged by an eerie illumination” (Against, p.182). Indeed, in Lew's eyes, the actual, ordinary wallpaper transforms into a virtual, ghastly space with virtual human-like living things surrounded by an eerie illumination. Shortly after that, in a restaurant, Lew experiences another virtual image in yet another trance-like state. When they bring his meal to his table, Lew starts to see virtual things beyond what "a fellow might reasonably expect" in the serving dish. Each section of the steak that he made with his knife reveals "new vistas" of "the intricately disposed axes and poly hedra, a race of very small though perfectly visible inhabitants" (Against, p.183). Most importantly, Lew has the capacity of avoiding death. After the transformation, the stereotypical detective character is able to become invisible and escape into an alternative dimension of the world to get away from any explosions without being even slightly hurt. ${ }^{2}$

There are also some very spectral characters (with super-terrestrial qualities) that seem to have duel actual/virtual lives. One telling example is Kieselguhr Kid, the legendary anarchist dynamiter whose identity and whereabouts remain a mystery in the course of the novel. Kieselguhr is a virtual figure that has exhausted the mining owners who are looking for him. His identity is so unfathomable that Lew complains to his boss, Nate Privett, the case of the Kieselguhr Kid is "a bitch, and growing more difficult every day" (Against, p.179) and decides to leave it aside. Even to the end of novel, this knot will remain unraveled by Pynchon, which adds to the mystery and virtual quality of the character. ${ }^{3}$ The

\footnotetext{
${ }^{1}$ As a member of the intricate mystical society (TWIT),Yashmeen is considered a Tzaddik in the organization. Yashmeen also has the ability to communicate via telepathy (Against, p.595).

${ }^{2}$ Similarly, Nicholas Nookshaft, the Grand Cohen of T.W.I.T., says he can jump into an explosion without being hurt since he can be transported to a Lateral-world in the fourth dimension (Against, p. 211). In addition, the nymphomaniacally obscene Pert or Ruperta Chirpingdon-Groin's experiences "being surrounded then by a queer luminous aura" (Against, p.896) and a levitation. After the "levitation," she descends into earth and reoccupies herself, but she never again pursues "her old career of determined pest" (p.896). It is worth mentioning, here Pynchon also reflects upon the virtual and mysterious force which is potential in music.

3 Amian (2008), talking about Pynchon's V. states that "Much of the uncertainty that characterizes Pynchon's novel" "stems from its reveling in this space of creative possibility" (p.70).
} 
faceless Kieselguhr Kid is similar to the virtual character, "Ned Ludd"; Pynchon in his essay opines that "Ned Ludd", the faceless, unidentified character which recurs in the temporary works, is based on the mysterious archetypes like "the Badass -- the djinn, the golem, the hulk, the superhero" which bash the frames of "the real or secular" ("Is it Ok to be a Luddite?"). Another spectral character is a woman named La Blanca. In Telluride, Frank happens to see "La Blanca" who was named for the white horse with "supernatural demeanor she was always seen to ride" (Against, p.287). La Blanca seems be not only dangerous and fearful like her husband, but also mysterious and virtual due to the "light of Heaven on her hair", her keeping distance scrupulously, her "bloodless" lips that in "the windy transparency" seem "to disappear, leaving her black-fringed eyes the only feature you'd recall after she'd gone by" (Against,p.288). ${ }^{1}$ Among many other virtual characters is Dally's uncanny boyfriend Hunter Penhallow, a Venician artist who just like Venice itself has a mysterious side to it. Penhallow has fought in a great war which has not occurred yet; he is "demobilized from a war that nobody knew about, obscurely damaged, seeking refuge from time, safety behind the cloaks and masks and thousand-named mists of Venezia" (Against, p.577).

\section{The Chums of Chance, the Virtual Heroes}

Arguably, the fictional world of the Chums of Chance can help us perceive "life higher than the "lived"" (Deleuze and Guattari, 1994, p.177). Chums who verge on Tom Swiftian fictional characters are both fictional characters of the novel and fictional characters in the fictional series referenced in the novel; they seem to be caricatural, innocent characters from a fairy or tall tales, fictional characters within fiction or "Some invisible narrative occupying [...] the passage of the day" (Against, p.418). As if, the harsh non-fiction world is too much for them; hence, they take solace in the virtual world of fiction and "[get] down to earth" not often. In the very beginning of the novel, the narrator informs us that Chums' existence is dependent on the virtual realms of fiction, and unlike the "harsh non-fictional world", the Chicago Fair that was "at once dream-like and real," "possessed the exact degree of fictitiousness to permit the boys access and agency". The narrator adds that "the ground population" who "regards them with contempt and pity" are very different from Chums (p.25). That is, the world of other fictional characters of the novel is "more real" while Chums' world is more virtual.

Chums' fictionality is so much that the narrator, who has very rarely used the metafiction in the novel, poignantly addresses the reader directly and makes an apology for not including enough detail, referring the readers to a fictitious book, The Chums of Chance in the Bowels of the Earth for more information on Chums' "intraterrestrial scherzo" that is their journey into the hollow Earth and their encounter with the army of gnomes (Against, p.117). Indeed, Chums' parts are the most metafictional sections of the novel. The parts that are related to Chums with their mostly virtual nature intersect the accounts of the real groundlings of the fiction (i.e., characters who are taken to be real in the context of the novel). That is, the earthbound characters or the surface dwellers of the actual/virtual world of the novel and the pure virtual world of Chums entangle and make the novel even more intriguing. While Chums enjoy several visits to the real world of the fictional novel, by nature, they prefer the fictional, the alternative world of the fiction. Nevertheless, Chums' being fictional or real in the world of novel is not something consistent or unfaltering; that is, nonfiction and fiction, the real and the imaginary are merged.

This perplexing state of the oscillation between fiction and nonfiction resurfaces many times in the course of the novel. At one point, Reef Traverse, being on his way to bring back Web's corps, reads "a dime novel, one of the Chums of Chance series, The Chums of Chance at the Ends of the Earth to his father's corps. Later on, Reef who deems the boys as "agents of a kind of extrahuman justice" and is enjoying "a sort of dual existence, both in Sorocco and at the Pole", sees "something familiar" in the sky, and the strange yet familiar thing is nothing but Chums' balloon that he is reading about; Reef says, "They're watching us, all right. And tonight I'll read you some more out of that story” (p.215). Perhaps, through Chums' quasi-fictive status, Pynchon wants to show that there is not a plain distinction between fiction and nonfiction and between virtual and actual, as Deleuze also maintains. In fact, fiction is the revelation of the virtual realms of life helping the reader to detach himself from the actual world. As Fairclough says, fictional discourses "not only represent the world as it is (or rather is seen to be), they are also projective, imaginaries, representing possible worlds which are different from the actual world, and tied in to projects to change the world in particular directions" (Fairclough, 2003, p.11). John Hughes (1997) also argues, "the artwork takes on the status of an event of the virtual expressed through its matter" (p.70). Indeed, in the pastiche-like tale of the boys, the line between the real and imaginary peters out as it gets hard to "tell fiction from non-fiction" (Against, p.37) in Randolph's words. In a word, Chums' inhabiting a fictionalized world, brings up the possibility of virtual world and poses ontological questions about what exactly is real in the reader.

Chums seem to be the embodiment of a virtual world of multiple realities as well as Pynchon's "impulse towards immanent transcendence" (Thomas, 2007, p.37). The novel starts with Chums' singling up all lines and finishes with their flight toward grace, and nowhere in the whole novel, the virtual forces are more bespoken than in the Airship Boys tales, the extra-dimensional aeronauts flying in a fantastical zeppelin with virtual capabilities and virtual gizmos. They are the proof that Pynchon, on his time machine, goes backward in time and resorts to the virtual world — a virtual world

\footnotetext{
${ }^{1}$ Similarly, the character of Fleetwood Vibe also seems to be mystifyingly virtual. The narrator says that Fleetwood may or may not be alive; that is, he might be a ghost (Against, p.164).
} 
of unlimited possibility — while an actual, nasty World War is around the corner. Chums are Pynchon's supermen who have the potentiality to defy the force of gravity, travel beneath the earth, use aether's qualities to move around, hold meetings with their fourth-dimensional counterparts, and age merely a few years in the course of the thirty years of the novel. This innocent gang is "everywhere, but invisible"; they are vectors "passing through the invisible, the 'imaginary', the unimaginable" and truly belong to where darkness is not disturbed by "light displaced from Hell" (Against, p.1082).

Chums can take a trip to dimensions outside the visible three dimensions, beyond this "known Creation", "beyond the space we know" (p.602). They live in their own meta-universe or a "realm of the counterfactual" (p.9); however, they have to visit our world. Indeed, Chums tale redirects the narrative from the actual into the virtual and vice versa. The world that other characters in the story are dwelling in is more actual/real and more sinister than the mostly virtual/real world of the innocent boys. However, these opposite worlds are seamlessly attached together. Just as Deleuzian virtual and actual are attached and create the reality, these two worlds are sewed by Pynchon to create a unique reality of the world of the novel and our own world in general. This seamless link is reflected in the interrelated relations of the characters, in the interspersed stories flowing from actual-oriented stories to virtual-oriented ones. Pynchon starts with Chums who then get to meet Lew Basnight who, as a private detective, is after the anarchists including Webb Traverse who is going to be killed by Scarsdale Vibe who financially supports Professor Vanderjuice who had been the balloonists' mentor. Of course, in between of these wide-ranging stories there are several associations of other virtual or actual stories like anarchists' resistance and holy Shambhala, and so forth, which are not unrelated to Chums' tales.

In addition, Chums' "usual unworldliness" (Against, p.35), as Vanderjuice deems them to be, is extendable to the implements they use. Even Chums' zeppelin is virtual as such; the narrator tells us that Inconvenience's propulsion mechanism, designed by Professor Vanderjuice, is "a perpetual-motion machine, in clear violation of themodynamical law" (p.6). Moreover, Chums, in their search for Shambhala, the magical place, use a device called "paramorphoscope" which is made of the magical crystals of Iceland Spar to read its map (that is "not a geographical map at all but an account of some spiritual journey" [p.248]); the calcite o is capable of separating "ordinary" beams of light from the "extraordinary" ones, which is the actual beams from the virtual beams, and Chums can decode the message from the Upper Hierarchy. Indeed, seeing via the extra-actual gadget, the balloonists get access to the virtual aspect of the world. Interestingly, this gadget revealing "the terrain at finer and finer scales" seems to function quite similarly to the modern Google earth software.

Further, Chums can have virtual visions which open the doors of the virtual worlds to them. For example, Miles, after saying goodbye to the Saksaul, experiences "extra-temporal excursions" (p.443) on board of the Inconvenience. The vision is a prophecy of the future Earth which seems to be disastrous. When he reports fully what he has seen of the future of the world, Chick thinks that he cannot count on the authenticity of this vision because Darby and him have already experienced a similar vision in the "timechamber" of Dr. Zoot with the same obscure message. However, we readers know that in their future of the novel--which is our past--the disastrous World War will happen and millions of people will be slaughtered. Hence, unlike Chick, we do not doubt the vision's accuracy; indeed, Pynchon sets Chick to function as a foil character or devil's advocate to his readers in this regard.

Each of the five Chums has certain virtual qualities, even the dog Pugnax that is literate and able to read classic literature. Yet, among Chums, perhaps Miles Blundell has the greatest grasp of the virtual world. Miles Blundell practices divination, communicates with the Fourth Dimension (Against, p.602), and has a "prophetic vision" (p.250). Once he tells one of his fellows, Lindsay, that at times he can temporarily be witness to peculiar thing: "like the electricity coming on--as if I can see everything just as clear as day, how...how everything fits together, connects", and soon he is taken back from this virtual journey "tripping over [his] feet again" (pp.194-195). Once, while passing an area in Venice, Miles spots ruined frescoes and gazes at them "as if they were maps"; later, he sees "the prophetic vision of St. Mark, but in reverse" with Miles becoming "some Being clearly not of the immediate region", a winged lion. This virtual experience is in line with Deleuzian ideas of becoming (animal) and difference. Indeed, Miles is "given" a virtual, "aptotic" (i.e., uninflected) potential of understanding wherein one is not able to "tell subject from object" (p.251) as he feels being himself as well as the winged Lion gaining virtual qualities.

Moreover, the steampunk balloonists' encounter with the legion of gnomes when traversing the hollow Earth is yet another virtual event involving Chums. In a portal near the South Pole, "diminutive combatants wearing pointed hats" -namely the local inhabitants of the underground world who have a huge civilization and a virtual-parallel world to the actual surface world-- signal a message to Chums saying that a legion of hostile gnomes have invaded them and seek assistance from Chums (p.117). Chums fight against the horde and narrowly escape the closing Northern portal. Here, "the surface world" is indeed the actual realm, and the underground realm with the miniature critters is the virtual one. However, the portals that connect the virtual, extraordinary underground world with the actual, secular world of humans start to shut down forever. In this fantastical episode of subterranean war, Pynchon verges on a flight of the imagination thus creating a line of flight from the actual world. The Hollow-Earth world, being a replica of the actual 
world on the ground, reminds us of the balloonist's dual virtual-actual existence; as Pynchon himself puts it, this is "the aeronauts' dual citizenship in the realms of the quotidian and the ghostly" (p.256). ${ }^{1}$

Moreover, Chums can deviate from a virtual existence to an actual one and vice versa by mutating "into imperfect replicas of who they once were", just like "the way ghosts are said to revisit places where destinies took a wrong turn, or revisit in dreams the dreaming body of one loved more than either might have known" (Against p.422). Their virtual qualities are even beyond their own imagination as a "brief aberration in their history", the mutation from virtual Chums to actual harmonica players, is quite perplexing to Chums themselves so much so that they have an existential doubt that they may not be the real Chums after all. They think that they might be a replica or mock-up of the real Chums, or even merely readers of the Chums Series helping Chums who are in need (p.423). Nevertheless, their earthly existence does not take long, and they return to Inconvenience, i.e., beyond the actual existence.

Interestingly, these virtual buddies manage to find themselves virtual mates. Chums, crossing the Rockies, find in the air "an invisible repetition of the material terrain beneath them" and "three-dimensional flows of cold air followed the flow of rivers far below". Now, the "Ætheronauts" experience a "moment of spiritual perplexity" while crossing "trajectories" (Against, p.1030) and meet girls who are even more mysterious than themselves. Being destined to marry, they encounter the girls who are "dressed like religious novices" with "metallic wings" which "could ever have been mistaken for angels' wings" (p.1030). This sisterhood, similar to Chums, is virtual and even more virtual since "this Ætherist sorority" "by the terms of their dark indenture" has decided to "never descend to Earth" (p.1030). Moreover, the girls' wings are "Æther-ærials” and function according Ætherodynamics rules which lay beyond the actual world. Æther has virtual and magical qualities, and the girls seem to have harnessed its virtual powers such as the virtual potentiality of dilating the Time and "making Time inversely proportional to viscosity". The girls and Chums couple in "a domesticity of escape and rejection", a line of flight from the terrestrial spaces "which is never entirely dreamed, from other worlds" (p.1030).

In the course of novel, the fate of Chums gets more and more virtual. The Inconvenience, housing Chums and their wives, grows "as large as a small city" with extraterrestrial qualities. It grows "so big that when people on the ground see it in the sky, they are struck with selective hysterical blindness and end up not seeing it at all" (p.1084). Now, the balloon is very similar to the Shambhala Chums had been after for a long time, a virtual world of unlimited possibility, wherein "any wish that can be made is at least addressed, if not always granted" (p.1085). Now that they have completely unshackled from the actual realm, Chums go further and further into the virtual realm where "It is no longer a matter of gravity-it is an acceptance of sky", a virtual realm pregnant with the invisible, transcendence, and "grace": "They know -Miles is certain- it is there, like an approaching rainstorm, but invisible. Soon they will see the pressuregauge begin to fall. They will feel the turn in the wind. They will put on smoked goggles for the glory of what is coming to part the sky. They fly toward grace" (p.1085). That is, Chums' flight towards grace is a flight from the actual space and time to an alternate dimension, a virtual glorious territory of alternative reality. This final journey takes the balloonists to the other the side of the world which is the unnamable and virtual realm of potentiality, difference, and becoming.

\section{REFERENCES}

[1] Amian, K. (2008). Rethinking postmodernism(s): Charles S. Peirce and the pragmatist negotiations of Thomas Pynchon, Toni Morrison, and Jonathan Safran Foer. Amsterdam: Rodopi.

[2] Bogue, R. (2011). Deleuze and Guattari and the future of politics: Science fiction, protocols and the people to come. Deleuze Studies, 5, 77-97.

[3] Boundas, C. V., \& Constantin V. B. (2014). Columbia companion to twentieth-century philosophies. Amsterdam, Netherlands: Amsterdam University Press.

[4] Buchanan, I. (2000). Deleuzism: A metacommentary. Durham: Duke University Press.

[5] Coffman, Ch. K. (2011). Bogmolism, Orphism, Shamanism: The spiritual and spatial grounds of pynchon's ecological ethic. InJ. Severs and L. Christopher (Eds), Pynchon's against the day: A corrupted pilgrim's guide(pp. 91- 115). Newark: U of Delaware.

[6] Colebrook, C. (2002). Gilles Deleuze. London: Routledge.

[7] Dalsgaard, I. H. (2011).Readers and trespassers: Time travel, orthogonal time, and alternative figurations of time in against the day. In J. Severs \& Ch. Leise (Eds), Pynchon's Against the Day: A Corrupted Pilgrim's Guide, (pp. 115-137). Newark: University of Delaware.

[8] Deleuze, G. (1988). Bergsonism. New York: Zone Books.

[9] Deleuze, G. (1994). Difference and Repetition. Trans. Paul Patton. New York: Columbia University Press, 1994. Print.

[10] Deleuze, G, Boyman, A, \&Rajchman, J. (2001). Pure immanence: Essays on a life. New York: Zone.

[11] Deleuze, G. (1995). Negotiations: 1972-1990. New York: Columbia University Press.

[12] Deleuze, G, \& Parnet, C. (1987). Dialogues. Trans. Hugh Tomlinson and Barbara Habberjam. New York: Columbia University Press.

[13] Deleuze, G., \& Guattari, F. (1987). A Thousand plateaus: Capitalism and schizophrenia. Minneapolis: University of Minnesota, 1987.

\footnotetext{
${ }^{1}$ Another one of the novel's most impressive fantastical events is also experienced by Chums. In the Sahara, Chums face a startling event in which the Earth bifurcates into the Earth and Counter-Earth with Chums being "on the Counter-Earth, on it and of it, yet at the same time also on the Earth they had never it seemed, left" (p.1021).
} 
[14] Deleuze, G., \& Guattari, F. (1994). What is philosophy? New York: Columbia University Press Print.

[15] Fairclough, N. (2003). Analysing discourse: Textual analysis for social research. London: Routledge.

[16] Gregory, F. (2012). Gilles Deleuze and the fabulation of philosophy, Powers of the False, Volume 1. Minneapolis: University of Minnesota Press.

[17] Foucault, M. (2010). What is an author? In M. Foucault and P. Rabinow (Eds), The Foucault Reader(pp. 101-120). New York: Vintage.

[18] Fowler, D. (1980). A reader's guide to gravity’s rainbow. Ann Arbor: Ardis.

[19] Hughes, J. (1997). Lines of flight: Reading Deleuze with Hardy, Gissing, Conrad, Woolf. Sheffield, England: Sheffield Academic.

[20] Hume, K. (2001). The religious and political vision of against the day. In J. Severs \& Ch. Leise (Eds), Pynchon's Against the Day: A Corrupted Pilgrim's Guide, (pp.167-191). Newark: University of Delaware.

[21] Koerner, M. R. (2010). The uses of literature: Gilles Deleuze's American Rhizome. Diss. Duke University.

[22] Mattessich, S. (2002). Lines of flight: Discursive time and countercultural desire in the work of Thomas Pynchon. Durham: Duke University Press.

[23] Parr, A. (2012).The Deleuze dictionary. Edinburgh: Edinburgh University Press.

[24] Pynchon, T. (2006). Against the day. New York: Penguin.

[25] Pynchon, T. (1984, October 28). Is It O.K. to Be a Luddite? . The New York Times. Retrieved from https://archive.nytimes.com/www.nytimes.com/books/97/05/18/reviews/pynchon-luddite.html.

[26] Phillip, R. (2003). That-which-new media studies-will-become. The Fibreculture Journal. Retrieved from http://journal.fibreculture.org/issue2/issue2_roe.html.

[27] Thomas, S. (2007). Pynchon and the political. London: Routledge.

[28] Wood, J. (2014, August 17). James Woods' classic takedown of faux-dickensian "hysterical realism". Retrieved from http://xiebq.blogspot.com/2014/08/james-woods-classic-takedown-of-faux.html.

Razieh Rahmani is a Ph.D. student in PLC at the State University of New York at Binghamton. Her research mainly focuses on literary theory, Deleuze, contemporary novels, and Pynchon. She has published a number of articles on Beckett, Pynchon, and Doctorow; also, she has translated some of Kurt Vonnegut's works into Persian. 